\title{
Influence of sex, maturity and reproduction on PCB and p,p'DDE concentrations and repartitions in the European hake (Merluccius merluccius, L.) from the Gulf of Lions (N.W. Mediterranean)
}

\author{
Xavier Bodiguel ${ }^{a}$ b, Véronique Loizeau $^{\mathrm{a},{ }^{*},}$, Anne-Marie Le Guellec ${ }^{\mathrm{a}}$, François Roupsard ${ }^{\mathrm{a}}$, Xavier \\ Philippon $^{\mathrm{a}}$ and Capucine Mellon-Duval ${ }^{\mathrm{b}}$

\footnotetext{
a IFREMER, Département de Biogéochimie et Ecotoxicologie, Technopôle Brest-Iroise, Pointe du Diable, BP70, 29280 Plouzané, France

b IFREMER, Département Halieutique Mediterranéen et Tropical, bd. J. Monnet BP171, 34203 Sète Cedex, France
}

*: Corresponding author : V. Loizeau, Tel.: +33 2982246 79; fax: +33 29822 45 48, email address : vloizeau@ifremer.fr

\begin{abstract}
:
The main objective of this work was to establish the influence of sex, maturity and reproduction on the contamination of the demersal fish Merluccius merluccius by organochlorine compounds. Polychlorinated biphenyls (PCBs) and p,p'DDE were quantified in muscle, liver and gonads of female and male hakes collected in the Gulf of Lions in 2004 and 2005. Observed levels appeared higher than the population of the Bay of Biscay and lower than the population of the Thyrrenian Sea. Contaminant fingerprints were roughly constant whatever the studied organ and the hake biological condition. Concentrations varied significantly according to the sex and maturity of hakes. Mature specimens were more contaminated than immature, and males presented higher levels than females. This sex effect can be linked to a lower growth rate of males, and a contaminant elimination during female spawning. Gonadal contamination depends on the importance of lipid content and increases with the maturation degree. Although the main organ of energy and PCB storage is the liver, muscle appears as the main contributor to the gonad contamination.
\end{abstract}

Keywords: Bioaccumulation; PCBs; p,p'DDE; Merluccius merluccius; Demersal fish; Mediterranean Sea 


\section{Introduction}

Organochlorine compounds such as Polychlorinated biphenyls (PCBs) and Dichlorodiphényltrichloroéthane (DDT) are synthetic chemicals that have been introduced into the environment since the 1920s. DDT was used as an insecticide, and PCBs, as a thermal stabilizer in a wide scale of applications, such as coatings, inks, flame retardants and paints, but their major applications were in electric appliances, heat transfer systems and hydraulic fluids. PCB open applications were banned in many countries in the 1970s (Stockholm Convention, 2003) and their use in close systems (such as capacitors and transformers) was limited since the 1990s. However, their high lipophilicity and environmental stability make them to persist in the environment for long periods, involving a wide geographical distribution. These compounds are considered among the most dangerous pollutants. They exhibit a broad spectrum of toxicological responses, including immunotoxicity, teratogenicity, endocrine disruption, reproductive deficits, and contribute to tumor and carcinoma development (Ahlborg et al., 1994). Because of their stability, long biological half-life, and high liposolubility, they may be bioaccumulated and biomagnified along food chains involving a wide range of trophic levels, with a potential risk for high trophic level predators (Borga et al., 2001; Fisk et al., 2001; Nfon and Cousins, 2006). The dietary intake, especially the consumption of marine organisms, is considered as one of the most important exposure source of PCBs for human population (Johansen et al., 1996; Pompa et al., 2003).

The European hake (Merluccius Merluccius) is an important ecological and commercial species in the ecosystem of the Gulf of Lions (N.W. Mediterranean). With a large spatial distribution from the coast to the continental slope, this species plays a fundamental ecological role in this area. This is a major focus for stock assessment on account that hake is the main commercial demersal species (Oliver and Massuti, 1995; Aldebert and Recasens, 1996) with catches principally taken on juveniles. Its bathymetric distribution, between 30 and 600 meters depth, depending on its length (Campillo et al., 1991). Hake goes up to the water column to eat, and its food is mainly made up of crustaceans and pelagic fishes depending on hake size (Bozzano et al., 1997; Cartes et al., 2004, Ferraton et al., 2007). In the Gulf of Lions, the spawning season runs throughout the year, peaking in autumn-early winter (Recasens et al., 1998). Although growth has been studied over a number of decades, age determination from recently tagged otolith readings in Atlantic (De Pontual et al., 2003; 2006) and from otolith microstructure readings in the Mediterranean Sea (Arneri and Morales-Nin, 2000; Morales-Nin and Moranta, 2004; Belcari et al., 2006) have called into question the previous results.

Due to a high trophic level, hake is potentially exposed to the bioaccumulation of organic compounds, especially in the Gulf of Lions. After, Bodiguel et al. (2008), the high levels of persistent halogenated compounds in Mediterranean hakes might be related to the Rhône River loads coming from urbanised and industrialised watershed in southern France. In fact, this river is polluted by extensive anthropogenic activities and is particularly exposed to PCBs (Babut and Miège, 2007). The bioaccumulation of organochorine compounds is however a complex phenomenon ruled by both physico-chemical properties of compounds and ecological and biological factors such as feeding behaviors, habitat, age, sex or state of health of the animals (Paterson, 2003; Bodin et al., 2007a; Di Bella et al., 2006). Nevertheless few studies describing organ-specific bioaccumulation (Fillmann et al., 2007), and especially in relation to the reproduction process. The aim of this study was to understand the influence of sex, maturation degree and reproduction on PCB and pp'DDE concentrations and distributions in muscle, liver and gonads of hake from the Gulf of Lions. 


\section{Material and methods}

\subsection{Sampling}

The study area is the Gulf of Lions, situated in the North Western Mediterranean Sea (fig. 1). This large continental shelf is exposed to important contaminant discharges from the Rhone River. The Rhone watershed represents about $130000 \mathrm{~km}^{2}$ and a quarter of France's population. Moreover, 20\% of French industrial activities are located in this catchment area, as well as some other agricultural and tourist activities (Anon., 2000). As hake cannot be considered as a sedentary fish since it reaches increasingly deeper waters as it gets older, fish samples were caught on the continental shelf (between 30 and 120 meters depth) during three bottom-trawl cruises (May 2004-2005; October 2004) and at the edge of canyons (>150 meters depth) during gillnets cruise in October 2006. Moreover, a complementary sampling was carried out in 2006 by IFREMER at the Sète Auction market. A total of 104 hakes or hake pools, from 6 to $70 \mathrm{~cm}$ total length (TL), were collected for organic contaminant analysis.

\subsection{Sample preparation}

Preliminary sample pre-treatment steps were performed as soon as possible on receipt of the fish. Specimens larger than $25 \mathrm{~cm}$ TL were primarily pre-treated on board whereas the smallest individuals were processed in the laboratory. Pre-treatment included total body weight, fish gutted weight, total length, macroscopic sex determination and dissection of tissues to cut off organs (muscle, liver and gonads). Only specimens $\geq 25 \mathrm{~cm}$ TL were sexually identifiable. Muscle, liver, as well as gonads were weighed and stored in precleaned glass jars at $-20^{\circ} \mathrm{C}$. In the laboratory, all sampled tissues were freeze dried, and grounded to obtain a fine homogeneous powder. Their water content was estimated from the weight lost during freeze drying. Finally, to obtain sufficient quantity of tissue powder to carry out contaminant analysis, each tissue, livers and muscles, of the smallest individuals $(<25$ $\mathrm{cm} \mathrm{TL}$ ) were pooled at each season per centimetric class.

\subsection{Chemical analysis}

PCB and pp'DDE analysis were carried according to the protocol described by Bodin et al. (2007b). Concisely, sample was extracted in a hot Soxhlet extraction apparatus (Soxtec) during $1.5 \mathrm{~h}$ with a hexane:acetone mixture (80:20). The amount of extracted fat was determined by gravimetric method. Then, two successive clean-up were performed on the extractible material. First, lipids and co-extractible material were destroyed by addition of concentrated sulphuric acid. Secondly, the cleaned extract was purified by adsorption chromatography on a Florisil column (Florisil, 60-100 mesh size, activated for $1.5 \mathrm{~h}$ at $500^{\circ} \mathrm{C}$, deactivated with $3 \%$ of demineralised water) eluted with pentane. Finally, PCB congeners and pp'DDE were analysed by gas chromatography with electron capture detector, on a HP 5890 series II equipped with a CP-Sil19 capillary column (60 m length, internal diameter 0.25 $\mathrm{mm}$, and $0.15 \mu \mathrm{m}$ phase film thickness) following optimized conditions described by JaouenMadoulet (2000). Seven indicator PCB congeners were measured (CB28, 52, 101, 118, 138, $153,180)$. However, the CB28 was always below the detection limit of $0.3 \mathrm{pg} \cdot \mu \mathrm{L}^{-1}$ and was consequently not taken into account in the data analysis. A few other congeners were also analysed to describe a larger range of chlorination, from 5 to 8 chlorine molecules (CB105, $110,128,132,149,156,170,187,194)$. They permit to check the appropriate resolution of the gas chromatography system, and could highlight underlying mechanisms acting on the distribution of organic contaminants in biota like bioaccumulation or biotransformation. 


\subsection{Quality control criteria}

The calibration system was performed within a rather wide range using a six-point calibration curve to define the linearity range of our detector (ECD) for all contaminants. The relative precision of the method was checked for this type of sample by analysing five aliquots of a homogeneous tissue preparation of hake muscle. The results showed standard deviations of less than $10 \%$ for all congeners, which points to the good reproducibility of the method. During the analysis of the real samples, analytical blanks were systematically measured every ten samples. The blank concentrations were always below those the concentrations of the lowest standards of all congeners. Finally, 10 replicates of a reference material, BCRCRM349 (Cod Liver Oil) were analysed in order to determine the accuracy of the method. PCB recoveries varied between 74 and 125\%, except for CB 105 which may interfere with a co-eluting compound. For p,p' DDE, recovery was $120 \%$. The concentrations of the real samples were not corrected as regards recoveries. Moreover, the RSD values ranged from 4 to $19 \%$, with a mean value of $10 \%$ for all PCBs. In the case of p,p'DDE, the RSD was $9 \%$. The results were in agreement with certified reference values and published data (Schantz, 1993). The protocol was validated by undertaking regular intercomparison exercises (QUASIMEME) in the laboratory.

\subsection{Data analysis and statistical treatment}

Hake growth in different areas is currently reconsidered (Garcia-Rodriguez and Esteban, 2002; De Pontual et al., 2006; Mellon-Duval et al., 2009). Consequently, hake age was calculate using recent data obtain in 2006 and 2007 by tagging experiments in the Gulf of Lions by Mellon-Duval et al. (2009). From these two years recaptured data $(n=200)$, they calculate a first estimate of a new Von Bertalanffy parameter $k$, considering L $\infty$ unchanged from previous estimate (Aldebert and Recasens, 1996) as follow:

Female: $L \infty=100.7, k=-0.236$; male: $L \infty=72.8, k=-0.239$.

The gonado-somatic index (GSI) commonly used to characterize the maturity phase of gonads of the hake was determined by the ratio between gonad weight and fish gutted weight.

A Principal Component Analysis was performed to facilitate the interpretation of the large set of data obtained throughout this study. Morphometric data were normally distributed, and PCB data followed a normal distribution after log-transformation, according to the ShapiroWilk test $(p<0.05)$. Then data on body weight, length, and PCB and pp'DDE concentrations expressed in dry weight $(\mathrm{dw})$ were subjected to correlation analysis using Pearson's coefficient. Additionally, the influence of size, sex, on PCB levels and fingerprints in hake were studying using Student tests. Statistical analyses were performed using Statistica Software 6.0. To estimate the relative part of PCB contamination in various organs, measured concentrations were expressed in quantity by organ. Total wet weight concentrations in whole individuals were defined using the following equation:

$[153]$ ind $=\frac{\left([153] \text { liver }^{*}(1-w l) * W l\right)+\left([153] \text { gonad }^{*}(1-w g) * W g\right)+\left([153] \text { muscle }^{*}(1-w m) * W m\right)}{T W}$

with: $\quad$ wl: \% of water in liver ; wg: \% of water in gonads; wm: \% of water in muscle; Wl: Liver; weight (g); Wg:: Gonad weight (g); Wm: Muscle weight (g); TW: Total Weight (g); [153]liver: CB153 concentration in liver (ng. g $\left.^{-1} \mathrm{DW}\right)$; [153]gonad : CB153 concentration in

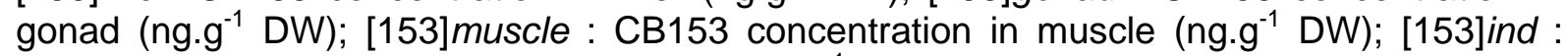
CB153 concentration in whole individual $\left(\mathrm{ng}^{-1} \mathrm{~g}^{-1} \mathrm{ww}\right)$. Total lipid concentrations in whole individuals were calculated with the same method. 


\section{Results and discussion}

\subsection{PCB concentrations and congener-pattern}

All 15 PCB congeners and pp'DDE were quantified in more than 95\% of the analysed samples. Concentrations and lipid contents (mean and range) of all determined congeners in muscle, liver and gonads of the European hake from the Gulf of Lions are reported in table 1. The dry weight concentrations of $2,2^{\prime}, 4,4^{\prime}, 5,5^{\prime}$ PCB congener (CB153) ranged within the following intervals: muscle, $10-200 \mathrm{ng} \mathrm{g}^{-1} \mathrm{dw}$; liver, $100-2500 \mathrm{ng}^{-1} \mathrm{~g}^{-1} \mathrm{dw}$; gonads, $5-450$ $n g \cdot g^{-1} \mathrm{dw}$. For all congeners and pp'DDE, the highest levels were recorded in livers, followed by muscle, then gonads, except for some females, where gonads were more contaminated then muscle. In particular, livers were about 5.4 to 37 times more contaminated than muscles and about 4.6 to 71 times more contaminated than gonads. To our knowledge, no data is available on the contamination of hake from the Gulf of Lions through PCBs. At the scale of NW Mediterranean, our values were lower than those reported by Naso et al. (2005) for hake from the Gulf of Naples (Thyrrenian Sea). Mean CB153 concentration in hake muscle from this area (1527 $\mathrm{ng} \cdot \mathrm{g}^{-1}$ lipid) was approximately two times higher than our measurement in the Gulf of Lions ( $797 \mathrm{ng} \cdot \mathrm{g}^{-1}$ lipid). The values were however 2 to 5 times higher than those reported for hake from Bay and Biscay (Bodiguel et al., 2008). When comparing to other fish species, the levels were comparable to concentrations observed in the deep sea fish Mora moro from the Gulf of Lions (Solé et al., 2001), but lower than those recorded in different top predators from the Mediterranean Sea, like tuna and swordfish (Stefanelli et al., 2002, 2004), shark (Storelli and Marcotrigiano, 2001) or Risso's dolphin (Storelli and Marcotrigiano, 2000). Furthermore, in the Mediterranean hake, the PCB fingerprints were characterized by the importance of the hexachlorobiphenyls, notably CB138 and CB153 which represent by far the major compounds of all samples, followed by heptachloro-biphenyls (CB180 and CB170). These recalcitrant congeners are also predominant in most biota (Boon et al., 1989), including marine organisms from the Mediterranean Sea, such as monkfish (Storelli et al., 2004) tuna (Stefanelli et al., 2002) or swordfish (Stefanelli et al., 2004). Due to their high octanol-water coefficients (log Kow > 6.5; Hawker and Connell, 1988), they are accumulated by marine organisms and are not metabolised, because of chlorine substitution positions (Bright et al., 1995; Kannan et al., 1995).

In addition, no significant differences in congener distribution among sex and tissues were observed in hake. Some authors reported also no differences of PCB profiles between fish tissues, like Monosson et al. (2003), between liver muscle and gonads in resident Mummichog from the Hudson River Estuary and Newark Bay (USA), or Bright et al. (1995), between liver and whole tissue in four-horn sculpin from Cambridge Bay and Queen Maud Gulf (Canada). Other studies suggested however a difference in PCB distribution between liver and other fish tissues. For example, Garcia et al. (2000) described that among tissues of the benthic Lepidorhombus boscii and the demersal Phycis blennoides from western Mediterranean, livers of both species were depleted in lower PCB congeners, and particularly in those containing meta and para vicinal $\mathrm{H}$-atoms. They conclude to a metabolic activity of these species for these congeners. In our study, the similarity of PCB profiles between tissues, PCB isomers with m,p- free positions included (PCB 52, 101, 110 and 149), is not sufficient to conclude that no PCB metabolism occurred in hake. Indeed, Solé et al. (2001) observed for example similar PCB profiles between liver and muscle of the deep-sea fish Mora moro from the Gulf of Lions (France), but showed a PCB metabolisation (isomers with $\mathrm{m}, \mathrm{p}$ - free positions ) by this species, by comparison with profiles observed in their preys. 


\subsection{Interrelations between samples}

Concentrations of 15 PCB congeners and p,p'DDE were measured in different organs (muscle, liver and gonads when possible) of 104 hakes. Those 48 parameters were determined in hake samples varying with biological characteristics, corresponding to various size, gender, sexual maturity or lipid fraction, leading to a very large data base. PCA (Principal Component Analysis) was performed on these data (104 x 48) in order to look for interrelations between samples and to compare their contaminant fingerprints, to give a more integrated picture of the contamination in hake from the Gulf of Lions. Chemical analyses contributing to less than $5 \%$ of the variance were excluded. The results of PCA are presented in a first plan, named loading-plot, which is defined by the first and the third principal component axis that together retain $55.6 \%$ of the variability (fig. 2).

Three large groups of variables appeared almost orthogonally. PCB congeners and pp'DDE in liver and muscle were represented on the right side, and PCB congeners in gonads on the left side. In each group, all vectors which represent PCB congeners pointed towards the same direction, indicating that all congeners varied approximately all together in each organ. PCB and pp'DDE levels in muscle seems correlated with hake size, whereas liver contamination is correlated with total lipid content, and gonads contamination with sex. These results highlight that the influence of the biological parameters like age (represented here by the size), sex and also lipid content on PCB levels, is not necessary the same function of the considered organ.

\subsection{Contamination variation with size, age and sex.}

One of the main result of the PCA was the influence of size on PCB and pp'DDE levels in hake muscle. As all PCB congeners and the pp'DDE are correlated, only one congener was used to illustrate the influence of biological parameters on PCB contamination. The CB153 was chosen for its systematic prevalence in all analysed samples. Significant positive relationship between body size and CB153 concentrations in the hake muscle was observed $(r=0.30, p<0.01)$, both sexes included. This relationship was also significant for liver and gonads ( $r=0.43, p<0.01$ and $r=0.48, p<0.01$ respectively). As described by several authors for other fish species (Mackay and Fraser, 2000), this concentration increase with size is due to the bioaccumulation property of $\mathrm{PCBs}$, to their relatively resistance to biotransformation and to their slow depuration rates by organisms.

As regards of CB153 concentrations in muscle and liver, a significant difference was found between of males and females. When comparing total concentrations of CB153 related to hake size (fig. 3a) and to hake age (fig. 3b), the significant contamination variation observed at equivalent size between males and females is not observable at equivalent age until hakes reach 2.5 years. This result can partially be attributed to a difference in growth rate between the two sexes. Females are described as having a faster growth rate than males (Aldebert and Recasens, 1996; Morales-Nin, 1998). At the same length, males are therefore older than females and have bioaccumulated more PCBs than females. This observation suggest that age is a more important factor than body size in the PCB accumulation process (Muir et al., 2003; Vives et al., 2005 ).

When considering age, a significant relationship was only observed with total concentrations of CB153 in males. For females an increase of CB153 concentrations was comparable to males until 2-2.5 years (38-42 cm TL), and a decrease then occurred (fig. 3). As described by Loizeau et al. (2001) in sea bass, a depuration of PCBs can occur during spawning of female hakes, and can give a complementary explanation of the contamination variation according to sex. 


\subsection{Influence of maturity}

As regards of the gonado-somatic index (GSI) commonly used to characterize the maturity phase of gonads of fish, the transition between the immature and mature stages occurred from $38 \mathrm{~cm} \mathrm{TL}$, with an increase gonadic index from less than $0.5 \%$ to more than $9 \%$ (fig. 4a). This result is in accordance with the study of Recasens et al. (1998), who describe the first maturity of $50 \%$ of females at $38 \mathrm{~cm} \mathrm{TL}$ in the gulf of Lions. This transition was not observed in males. The increase of female GSI was coupled with an increase of PCB concentrations in gonads. Figure $4 \mathrm{~b}$ shows that CB153 concentrations in female gonads jumped from less than $50 \mathrm{ng} \cdot \mathrm{g}^{-1} \mathrm{~d} . \mathrm{w}$. to more than $450 \mathrm{ng} \cdot \mathrm{g}^{-1} \mathrm{~d}$.w., while CB153 concentrations in male gonads did not exceed $60 \mathrm{ng} \cdot \mathrm{g}^{-1} \mathrm{~d}$.w. The evolution of PCB concentrations in gonads was then similar and positively correlated to GSI in females $(r=$ $0.65, p<0.01)$.

It appears that the mobilisation of PCBs toward gonads takes place during female maturation but not during that of the males. As a consequence, contaminants accumulated in the female gonads will be expelled during spawning, thus resulting in a relative depuration in females. Therefore, contamination differences between sexes were amplified due to contaminant depuration among females. The reproductive process has been also reported to decrease the body burden of persistent contaminants in various animals. The elimination of pollutants through spawning also occurs in other fish species (Swackhamer et al., 1988; Loizeau et al., 2001), mollusks (Hummel et al., 1989), and crustaceans (Mcmanus et al., 1983 ; Bodin et al., 2007a). Previous observations on fish related to size also show higher PCB accumulations in males than in females (Olsson et al., 2000; Vives et al., 2005). Finally, the phenomenon of PCB bioaccumulation in males but not in females because of contaminant elimination during the reproductive process is also observed in aquatic mammals (Nakata et al., 1995).

\subsection{Influence of lipid contents}

It is generally accepted that PCBs enter in marine organisms with lipids of ingested food (Hites et al., 2004) and their distribution in organs and tissues are strongly influenced by their lipid contents (Henshel and Sparks, 2006 ; Antunes et al., 2007). In this study, lipid contents were determined in muscle, liver and gonads of females and males. They varied within broader intervals in gonads (7-30 \%) and liver (20-88 \%) than in muscle (1-13\%) (table 1). In order to examine the influence of lipids on PCB concentrations, CB153 concentrations in each analysed tissue were plotted against its lipid content (fig. 5). In gonads (fig. 5a), lipid contents were correlated with CB153 concentrations in females $(r=0.54, p<0.01)$, and a significant positive relationship between GSI and lipid content was also observed $(r=0.86$, $\mathrm{p}<0.01$ ). Lipid contents and CB153 concentrations in male gonads were however always low. This result suggest that PCBs are mobilized into gonads linked to lipids during egg synthesis. In muscle (fig. 5b), the CB153 concentration in females varied linearly with lipids ( $r$ $=0.37, p<0.01)$. This relation was however no significant in the case of male $(r=0.32, p>$ 0.05). In liver (fig 5c), CB153 concentrations were not correlated with lipids, either in males and females, and both lipid contents and CB153 concentrations were highly variables. This result is in accordance to previous study on PCB in sardine from the Portuguese (Antunes et al., 2007). With a high lipid content, liver appears as the main storage organ in hake, as lipids constitute the main energy reserves in fish (Médale et al., 2003). Liver can then be considered as an energy buffer with a lipid content varying function of intake and expenditure energy. This feature can be at the origin of the poor correlation observed between lipid contents and PCB levels in hake because potential elimination of PCBs may not occur at the same time that lipids consumed. 


\subsection{Repartition and contamination levels function of maturity}

Various stages of developments were defined to apprehend the relative distribution of PCBs in the different hake organs. Recasens et al., (1998) describe the first maturity length of $50 \%$ of individuals at $28.8 \mathrm{~cm}$ TL for males and $38.0 \mathrm{~cm}$ TL for females. This size can attain $50 \mathrm{~cm}$ TL for females. According to these results, six stages were considered: 1 - The immature and undetermined sex hakes (TL $<25 \mathrm{~cm} ; \mathrm{n}=5$ ) for which gonads are not taken into account; 2The immature females $(25<T L<35 \mathrm{~cm} ; \mathrm{n}=5)$; 3 - The mature males $(T L>28 \mathrm{~cm} ; \mathrm{n}=6)$; 4The females in their $1 \mathrm{st}$ maturity $(n=5)$; 5 - The mature females $>50 \mathrm{~cm}$ TL with $\mathrm{GSI}>5 \%(\mathrm{n}$ $=3)$; 6 - The mature females $>50 \mathrm{~cm} \mathrm{TL}$ with $\mathrm{GSI}<1 \%(n=3)$.

Organ contribution to the total PCB body burden and total PCB concentration are presented in figure 6 in each stage, with the example of CB153. Results presented below for the CB153 are applicable to the other PCB congeners studied and pp'DDE. CB153 concentration in whole fish illustrates the bioaccumulation phenomena for hake males and confirms the partial decontamination of females after the first spawning. For all maturity stages, liver was the major contributor to the total PCB body burden (50.6 - 80.5\%). However PCB distribution in tissues was different according to the considered maturity stages. Undetermined sex hakes and mature males presented the lowest PCB proportions in liver $(61 \pm 12$ and $53 \% \pm 7.7$ respectively) and the highest in muscle (39 \pm 6.1 and $46 \% \pm 8.5$ ) respectively). In females, PCB proportions in liver appeared relatively stable, around $75 \%( \pm 3.03)$ of the total body burden, whatever the maturity stage. As expected, the PCB proportion in female gonads was higher in mature specimens than in immature ones. The PCB proportion in muscle appeared variable and complemented to gonads. This relation suggests that the main PCB quantity mobilized toward gonads during female maturation (oogenesis) is mobilized from muscle. Although the main organ of energy and PCB storage is the liver, muscle is therefore the main contributor to the gonad contamination. As suggested by Antunes et al. (2007) for sardines, this observation do not exclude a potential PCB transfer from liver to gonads, because an eventual PCB depuration of the liver could be compensate by compounds arriving via food. Nevertheless, this trend corroborate and could be an explanation to observations of other authors in other fish. Elskus et al. (1994) indicate that the reproductive status does not strongly or consistently influence PCB content in winter flounder liver, and suggest that the redistribution of $\mathrm{PCB}$ from liver to gonad might not substantially influence liver PCB content. Sole et al. (2001) observed a decrease of PCB concentrations in muscle of the deep-sea fish Mora moro with size, coupled with an increase of liver concentrations, but without consistency explanation. Finally, additional studies would be desirable to explain more in depth the transfer mechanism of PCB stored in the different organs to gonads.

\section{Conclusion}

This study presents variations of PCB and pp'DDE contamination in muscle, liver and gonad of male and female hake from the Gulf of Lions. Observed levels appeared higher than the population of the Bay of Biscay and lower than the population of the Thyrrenian Sea. Contaminant fingerprints were roughly constant whatever the studied tissue and the hake biological condition. Results highlight the influence sex, maturation degree and reproduction on levels and kinetic of PCBs and pp'DDE. Higher levels observed in males compared than females can be linked to a lower growth rate of males, and a contaminant elimination during female spawning. Spawning represents an important mechanism for the elimination of contaminants. Although the main organ of energy and PCB storage is the liver, muscle is the main contributor to the gonad contamination. Finally, the results show the necessity to taken into account the processes of maturity and reproduction cycle when modeling the bioaccumulation of persistent hydrophobic contaminants in fish, and especially the role of muscle in the gonad contamination. 


\section{Acknowledgments}

This work was partially funded by the Regional Council of Languedoc-Rousillon. Moreover, we would like to thank the crew of the IFREMER boat "L'Europe" for making the sampling possible. The authors are also grateful to Pierre Bodenes for drawing the map, Mireille Harmelin-Vivien and Luisa Metral for their assistance.

\section{References}

Ahlborg, U.G., Hanberg A., 1994. Toxic equivalency Factors for dioxon-like PCBs. Environ. Sci. Pollut. Res. Int., 1, 67-68.

Aldebert, Y., Recasens, L., 1996. Comparison of methods for stock assesment of European hake Merluccius merluccius in the Gulf of Lions (Northwestern Mediterranean). Aquat. Living Resour., 9, 13-22.

Anonyme, 2000. Préambule du schéma directeur d'aménagement et de gestion des eaux (SDAGE) du bassin Rhône Mediterranée. http://www.rhonemediterranee.eaufrance.fr/sdage/documents/panoramique-2000/panor002.pdf

Anonyme, 2003. United Nations Environmental Programme Chemicals. Stockholm convention on the reduction and/or elimination of the releases of persistent organic pollutants. Geneva, Switzerland.

Alheit, J., Pitcher, T.J., 1995. Hake Fisheries, Ecology and Markets. Fish and Fisheries Series 15. Chapman \& Hall, London, 478 p.

Antunes P., Amado J., Vale C., Odete G., 2007. Influence of the chemical structure on mobility of PCB congeners in female and male sardine (Sardina pilchardus) from Portuguese coast. Chemosphere, 69, 395-402.

Arneri, E., Morales-Nin, B., 2000. Aspects of the early life history of European hake from the central Adriatic . J. of Fish Biol., 56 (6), 1368-1380.

Babut M., Miège C., 2007. Contamination des poissons et des sédiments du Rhône par les polychlorobiphényles. Rapport Cemagref, $37 \mathrm{p}$.

Belcari, P., Ligas, A., and Viva, C., 2006. Age determination and growth of juveniles of the European hake, Merluccius merluccius (L., 1758), in the northern Tyrrhenian Sea (NW Mediterranean). Fisheries Research, 78 (2-3), 211-217.

Bodiguel X., Tronczyński J., Loizeau V., Munschy C., Guiot N., Le Guellec A.M., Olivier N., Roupsard F., Mellon C., 2008. Classical and novel organohalogen compounds (PCBs and PBDEs) in hake (M. merluccius, L.) from Mediterranean and Atlantic coasts (France). Environemental Toxicology 2008, Witt Press, 157-167.

Bodin, N., Caisey X., Abarnou, A., Loizeau, V., Latrouite, D., Le Guellec, A.M., Guillou, M., 2007a. Polychlorinated biphenyl contamination of the spider crab (Maja brachydactyla): Influence of physiological and ecological processes. Env. Tox. and Chem., 26, 454-461.

Bodin, N, Abarnou, A, Le Guellec, A-M, Loizeau, V, Philippon, X. 2007b. Organochlorine contaminants in decapod crustaceans from the coasts of Brittany and Normandy (France). Chemosphere, 67, S36-S47.

Boon, J.P., Eijgenraam, F., Everaarts, J.M., Duinker, J.C.A., 1989. Structure-activity relationship (SAR) approach towards metabolism of PCBs in marine animals from different trophic levels. Mar. Environ. Res., 27 (3-4), 159-176. 
Borgå, K, Gabrielsen, G.W., Skaare, J.U., 2001. Biomagnification of organochlorines along a Barents Sea food chain. Environ. Pollut., 113, 187-198.

Bozzano, A., Recasens, L., Sartor, P., 1997. Diet of the European hake (Merluccius merluccius) in the Western Mediterranean (Gulf of Lion). Sci. Mar., 61, 1-8.

Bright, D.A., Grundy, S.L., Reimer, K.J., 1995. Differential Bioaccumulation of Non-orthoSubstituted and Other PCB Congeners in Coastal Arctic Invertebrates and Fish. Environ. Sci. Technol., 29, 2504-2512.

Campillo, A., Aldebert, Y. Bigot, J.L., Liorzou, B., 1991. Répartition des principales espèces commerciales du Golfe du Lion en fonction des saisons (et plus particulièrement des groupes 0 et 1). FAO Rapp. Pêche, 447, 103-118.

Cartes, J.E., Rey, J., Lloris, D., Gil de Sola, L., 2004. Influence of environmental variables on the feeding and diet of European hake (Merluccius merluccius) on the Mediterranean coasts. J. Mar. Biol. Assoc. UK, 84, 831-835.

De Pontual, H., Bertignac, M., Battaglia, A., Bavouzet, G., Moguedet, P. Groison, A. 2003. A pilot tagging experiment on European hake (Merluccius merluccius): methodology and preliminary results. ICES J. Mar. Sci., 60, 1318-1327.

De Pontual, H., Groison, A.L., Pineiro, C., Bertignac, M., 2006. Evidence of underestimation of European hake growth in the Bay of Biscay, and its relationship with bias in the agreed method of age estimation. ICES J. Mar. Sci., 63, 1674-1681.

Di Bella, G., Licata, P., Bruzzese, A., Naccari, C., Trombetta, D., Turco, V.L., Dugo, G., Richetti, A., Naccari, F., 2006. Levels and congener pattern of polychlorinated biphenyl and organochlorine pesticide residues in bluefin tuna (Thunnus thynnus) from the Straits of Messina (Sicily, Italy). Environ. Int., 32, 705-710.

Ferraton F., Harmelin-Vivien M., Mellon-Duval C., Souplet A., 2007. Spatio-temporal variation in diet may affect condition and abundance of juvenile European hake (Merluccius merluccius) in the Gulf of Lions (NW Mediterranean). MEPS, 337, 197-208.

Filmann, G., Hermanns, L., Filemen, T., Readman, J., 2007. Accumulation patterns of organochlorines in juveniles of Arctocephalus australis found stranded along the coast of Southern Brazil. Environ. Pollut., 146, 262-267.

Fisk, A.T., Hobson, K.A., Norstrom, R.J., 2001. Influence of chemical and biological factors on trophic transfer of persistent organic pollutants in the Northwater Polynya marine food web. Environ. Sci. Technol., 35, 732-738.

Garcia, L.M., Porte, C., Albaiges, J., 2000. Organochlorinated Pollutants and Xenobiotic Metabolizing Enzymes in W. Mediterranean Mesopelagic fish. Mar. Poll. Bull., 40, 764-768.

Garcia-Rogriguez, M., Esteban, A. 2002. How fast does hake grow? A study on the Mediterranean hake (Merluccius merluccius L.) comparing whole otoliths readings and length frequency distributions data. Sci. Mar., 66 (2), 145-156.

Hawker, D. W., and Connell, D. W., 1988. Octanol-water partition coefficients of polychlorinated biphenyl congeners. Environ. Sci. Technol., 22, 382-387.

Henshel, D.S and Sparks, D.W., 2006. Site-specific PCB-linked Interspecies Differences in Organ Somatic Indices. Ecotoxicology, 15, 9-18.

Hites R.A., Foran J.A., Carpenter D.O., Hamilton M.C., Knuth B.A., Schwager S.J., 2004. Global assessment of organic contaminants in framed salmon. Science, 303, 226-229.

Hoekstra, P.F., O'Hara, T.M., Fisk, A.T., Borgå, K., Solomon, K.R., Muir, D.C.G., 2003. Trophic transfer of persistent organochlorine contaminants (OCs) within an Arctic marine food web from the southern Beaufort-Chukchi Seas. Environ. Pollut., 124, 509-522.

Hummel, H., UitOudeGroeneveld J.P., Nieuwenhuise, J., van Liere, J.M., Bogaards, R.H., de Wolf, L., 1989. A relation between PCB concentrations and reproduction in mussels Mytilus edulis. Mar. Environ. Res., 28, 489-493.

Jaouen-Madoulet, A., 2000. Distribution et effet biologiques des PCB et HAP dans les organismes de l'estuaire de Seine. PhD thesis, Le Havre University, 244 p.

Johansen, H.R., Alexander, J., Rossland O.J., Planting, S., Lovik, M., Gaarder, P.I., Gdynia, W., Bjerve K.S., Becher, G., 1996. PCDDs, PCDFs, and PCBs in human blood in relation to 
consumption of crabs from a contaminated fjord area in Norway. Environ Health Perspect., 104, 756-764.

Kannan, N., Reusch, T.B.H., Schultz-Bull, D.E., Petrick, G, Duinker, J.C., 1995. Clorobiphenyls: model compound for metabolism in food chain organisms and their potential use as ecotoxicological stress indicators by application of the metabolic slope concept. Environ. Sci. and Technol., 29 , 1851-1859.

Loizeau, V., Abarnou, A., Menesguen, A., 2001. A Model of PCB Bioaccumulation in the Sea Bass (Dicentrarchus labrax) Food Web from the Seine Estuary (Eastern English Channel). Mar. Poll. Bull., 43, 242-255.

Mackay, D. and Fraser, A., 2000. Bioaccumulation of persistent organic chemicals: mechanisms and models. Environ. Pollut., 110, 375-391.

McManus, G.B., Wyman, K.T., Peterson, W.T., Wurster, C.F., 1983. Factors affecting the elimination of PCBs in the marine copepod Acartia tonsa. Estuarine Coastal Shelf Science, 17, 421-430.

Médale, F., Lefèvre, F., Corraze, G., 2003. Qualité nutritionnelle et diététique des poissons. Constituants de la chair et et facteurs de variation. Cahiers de Nutrition et de Diététique (FRA), 38, 37-44.

Mellon-Duval, C., de Pontual, H., Métral, L, Quemener, L, 2009. Growth of the European hake (Merluccius merluccius L.) in the Gulf of Lions based on conventional tagging. ICES, J. Mar. Sci, 67, xxx-xxx.

Monosson, E., Ashley, J.T.F., McElroy, A.E., Woltering, D., Elskus, A.A., 2003. PCB congener distributions in muscle, liver and gonad of fundulus heteroclitus from the lower Hudson River Estuary and Newark Bay. Chemosphere, 52, 777-787.

Morales-Nin, B., Tores, G.J., Lombarte, A., Recasens, L., 1998. Otolith growth and age estimation in the European hake. J. of Fish Biol., 53, 1155-1168.

Morales-Nin, B., Moranta, J., 2004. Recruitment and post-settlement growth of juvenile Merluccius merluccius on the western Mediterranean shelf. Sci. Mar., 68, 399-409.

Muir, D., Savinova, T., Savinov, V., Alexeeva, L., Potelov, V., Svetochev, V., 2003. Bioaccumulation of PCBs and chlorinated pesticides in seals, fishes and invertebrates from the White Sea, Russia. Sci. of the tot. environ., 306, 111-131.

Naso, B., Perrone, D., Calmera Ferrante, M., Bilancione, M., Lucisano, A., 2005. Persistent organic pollutants in edible marine species from the Gulf of Naples, Southern Italy. Sci. of the tot. environ., 343, 83-95.

Nakata, H, Tanabe, S, Tatsukawa, R, Amano, M, Miyazaki, N, Petrov, EA, 1995. Persistent organochlorine residues and their accumulation kinetics in Baikal seal (Phoca sibirica) from Lake Baikal, Russia. Environ. Sci. and Technol. 29, 2877-2885.

Nfon, E., Cousins, I.T., 2006. Interpreting time trends and biomagnification of PCBs in the Baltic region using the equilibrium lipid partitioning approach. Environ. Pollut., 144, 994-1000. Oliver, P., Massuti, E., 1995. Biology and fisheries of western Mediterranean hake (M. merluccius). In Alheit, J. and Pitcher, T.J., 1995. Hake. Fisheries, Ecology and Markets. Fish and Fisheries Series 15, Chapman \& Hall, London, 181-202.

Olsson, A., Valters, K. and Burreau, S., 2000. Concentrations of organochlorine substances in relation to fish size and trophic position: a study on perch (Perca fluviatilis L.). Environ. Sci. and Technol., 34, 4878-4886.

Paterson, G., Drouillard, K.G., Hagen, H.J., Haffner, G.D., 2003. Persistent Organic Pollutants in Forage Fish and Their Relation to Age, Size, and Diet. Global Threats to Large Lakes: Managing in an Environment of Instability and Unpredictability. p. 122.

Pompa, G, Caloni, F, Caloni, F, Pompa, G, Fracchiolla, ML., 2003. Dioxin and PCB contamination of fish and shellfish: assessment of human exposure. Review of the international situation. Vet. Res. Comm., 27, 159-167.

Pitcher, T.J., 1995. The impact of pelagic fish behaviour on fisheries. Sci. Mar. (Barcelona), 59, 3-4. 
Recasens, L., Lombarte, A., Morales-Nin, B., Torres, G.J., 1998. Spatiotemporal variation in the population structure of the European hake in the NW Mediterranean. J. Fish. Biol., 53, 387-401.

Schantz, M.M., Parris, R.M., Kurz, J., Ballschmite,r K., Wise, S.A., 1993. Comparison of methods for the gas-chromatographic determination of PCB congeners and chlorinated pesticides in marine reference materials. Fresenius J. Anal. Chem., 346, 766-778.

Solé, M., Porte, C., Albaiges, J., 2001. Hydrocarbons, PCBs and DDT in the NW Mediterranean deep-sea fish Mora moro. Deep-Sea Reseach, 48, 495-513.

Stefanelli, P., Ausili, A., Ciuffa, G., Colasanti, A., Di Muccio, S., Morlino, R., 2002. Investigation of Polychlorobiphenyls and Organochlorine Pesticides in Tissues of Tuna (Thunnus thynnus) from the Mediterranean Sea in 1999. Bull. Environ. Contam. Toxicol., 69, 800-807.

Stefanelli, P., Ausili, A., Muccio, A.D., Fossi, C., Muccio, S.D., Rossi, S., Colasanti, A., 2004. Organochlorine compounds in tissues of swordfish (Xiphias gladius) from Mediterranean Sea and Azores islands. Mar. Poll. Bull., 49, 938-950.

Storelli, M.M., Marcotrigiano, G.O., 2000. Persistent Organochlorine Residues in Risso's Dolphins (Grampus griseus) from the Mediterranean Sea (Italy). Mar. Poll. Bull., 40, 555-558. Storelli, M.M., Marcotrigiano, G.O., 2001. Persistent organochlorine residues and toxic evaluation of polychlorinated biphenyls in sharks from the Mediterranean Sea (Italy). Mar. Poll. Bull., 42, 1323-1329.

Storelli, M.M., Storelli, A., D'Addabbo, R., Barone, G., Marcotrigiano, G.O., 2003. Polychlorinated biphenyl in seafood: contamination levels and human dietary exposure. Food Chemistry, 82, 491-496.

Storelli, M. M., Storelli, A., Barone, G., Marcotrigiano, G. O., 2004. Polychlorinated biphenyl and organochlorine pesticide residues in Lophius budegassa from the Mediterranean Sea (Italy). Mar. Poll. Bul., 48, 743-748.

Swackhamer, D.L., Hites, R.A., 1988. Occurrence and bioaccumulation of organochlorine compounds in fishes from Siskiwit Lake, Isle Royale, Lake Superior. Environ. Sci. and Technol., 22, 543-548.

United Nations Environmental Programme Chemicals. 2003. Stockholm Convention on the Reduction and/or Elimination of the Releases of Persistent Organic Pollutants. Geneva, Switzerland.

Vives, I., Grimalt, J.O., Ventura, M., Catalan, J., Rosseland, B.O., 2005. Age dependence of the accumulation of organochlorine pollutants in brown trout (Salmo trutta) from a remote high mountain lake (Redo', Pyrenees). Environ. Pollut. 2, 343-350.

Voldner, E.C., Yi-Fan, L., 1995. Global usage of selected persistent organochlorines. Sci. of the tot. environ., 160/161, 201-210. 


\section{Figures}

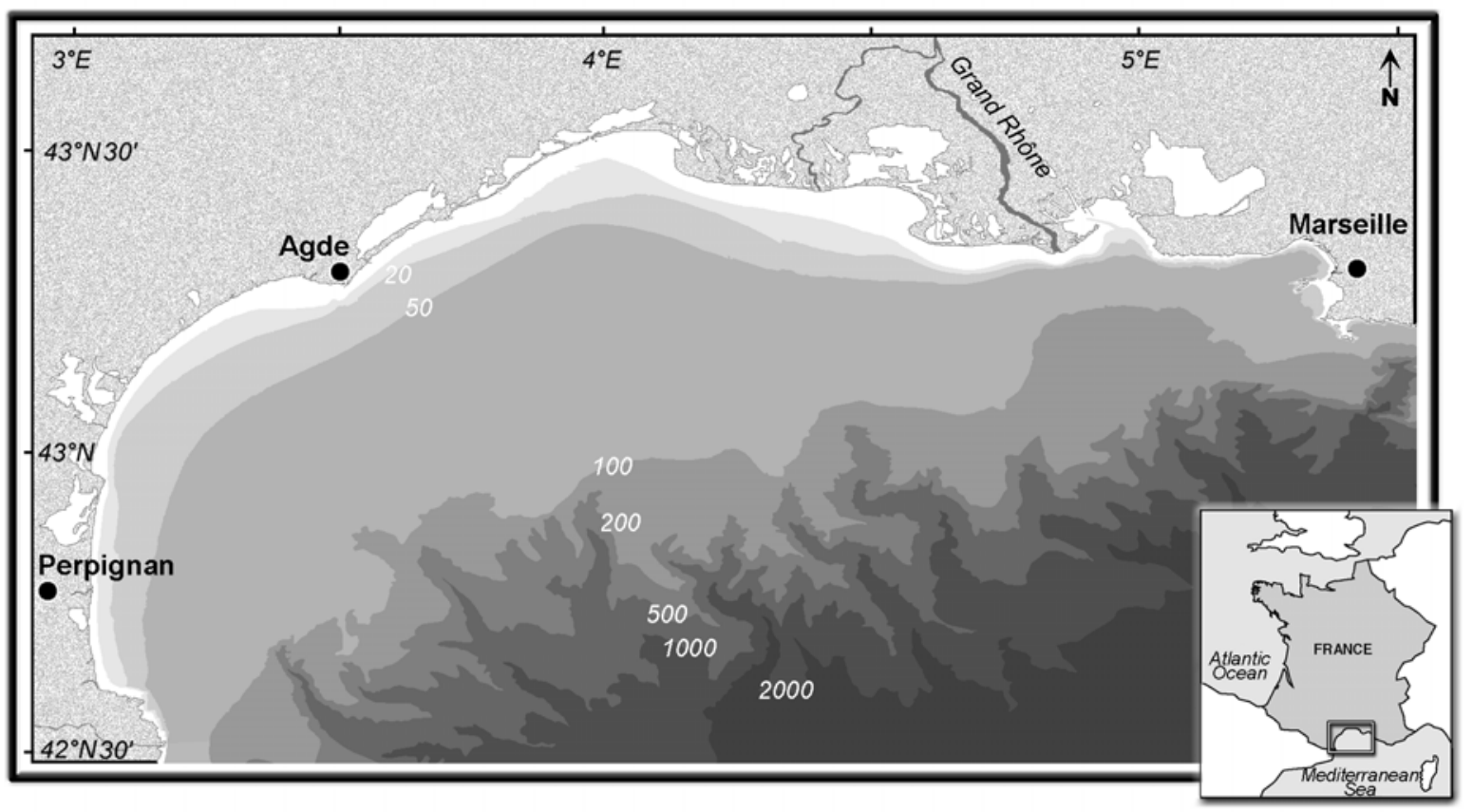

Figure 1: Map of the study area: the Gulf of Lions. 


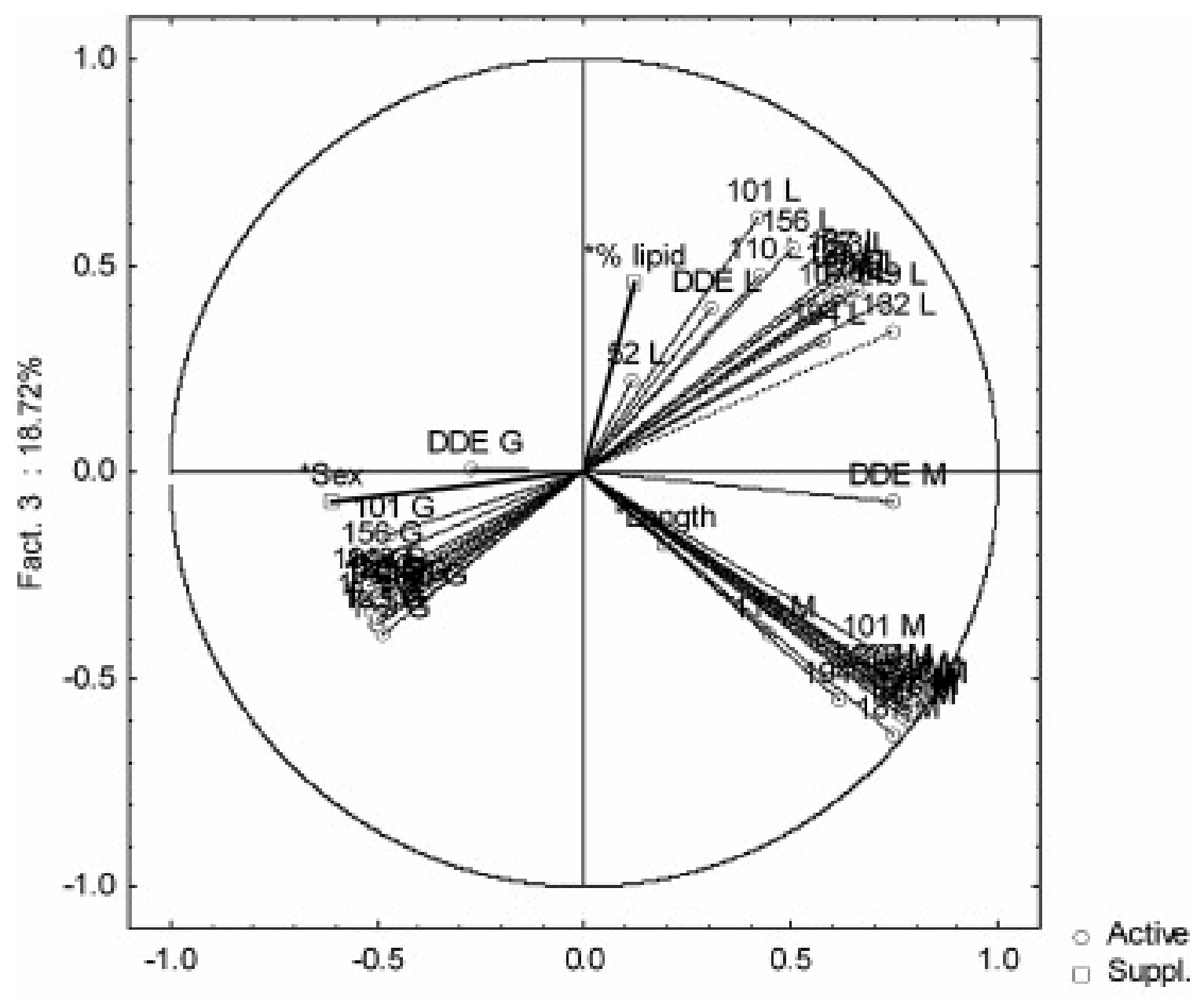

Fact. $1: 36.83 \%$

Figure 2: Principal Component Analysis of analysed PCB concentrations in muscle (M), liver $(\mathrm{L})$ and gonads $(\mathrm{G})$ of the hake from the Gulf of Lions. Projection of the standardized variables (PCB congeners) and explicative variables (Sex, Length and \% Lipid) in the principal plane. 

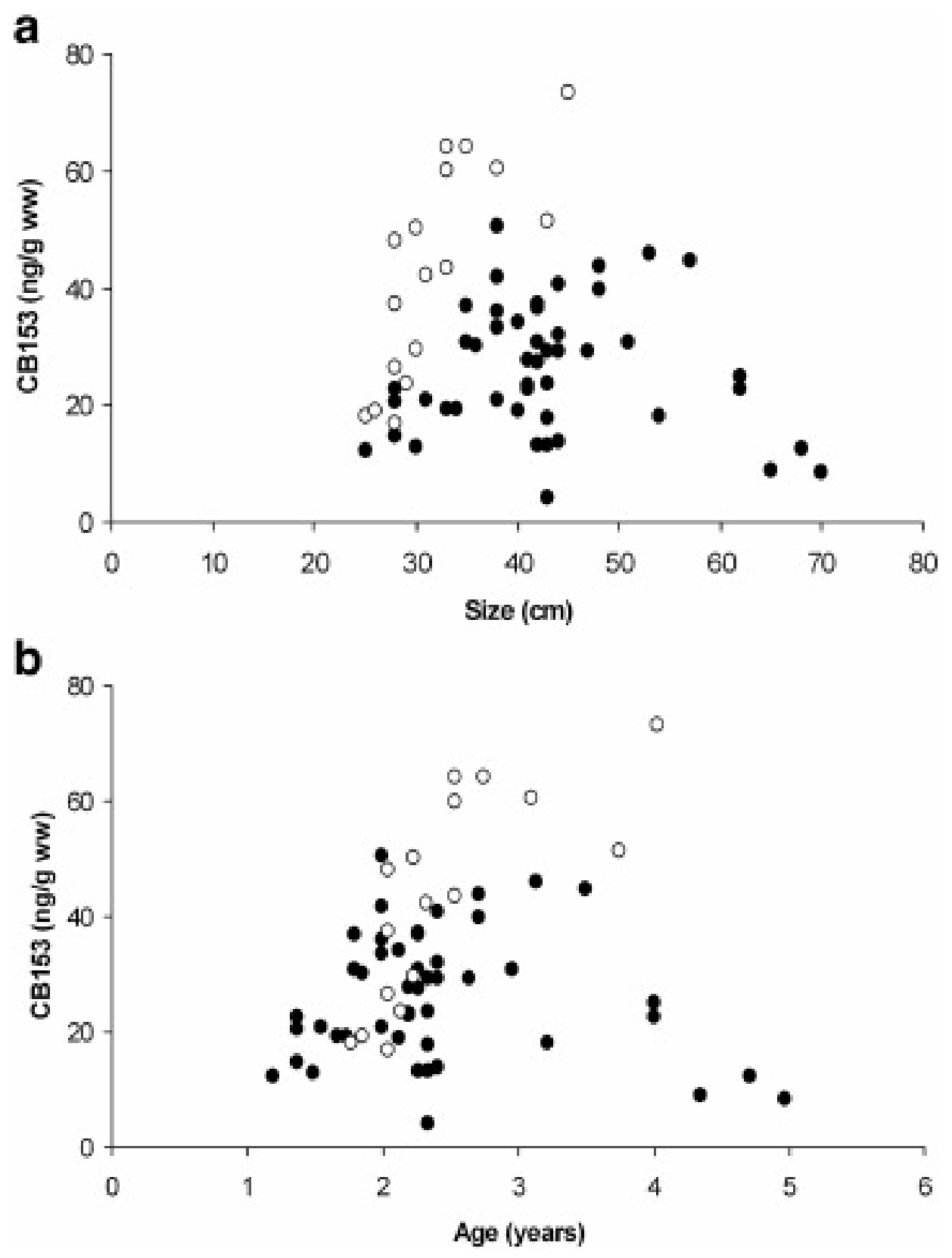

Figure 3: Relationship between CB153 concentrations in whole fish (ng. $\mathrm{g}^{-1} \mathrm{ww}$ ) and a) hake size $(\mathrm{cm})$, and b) age (years). Females and males are represented with black and white circles respectively. 

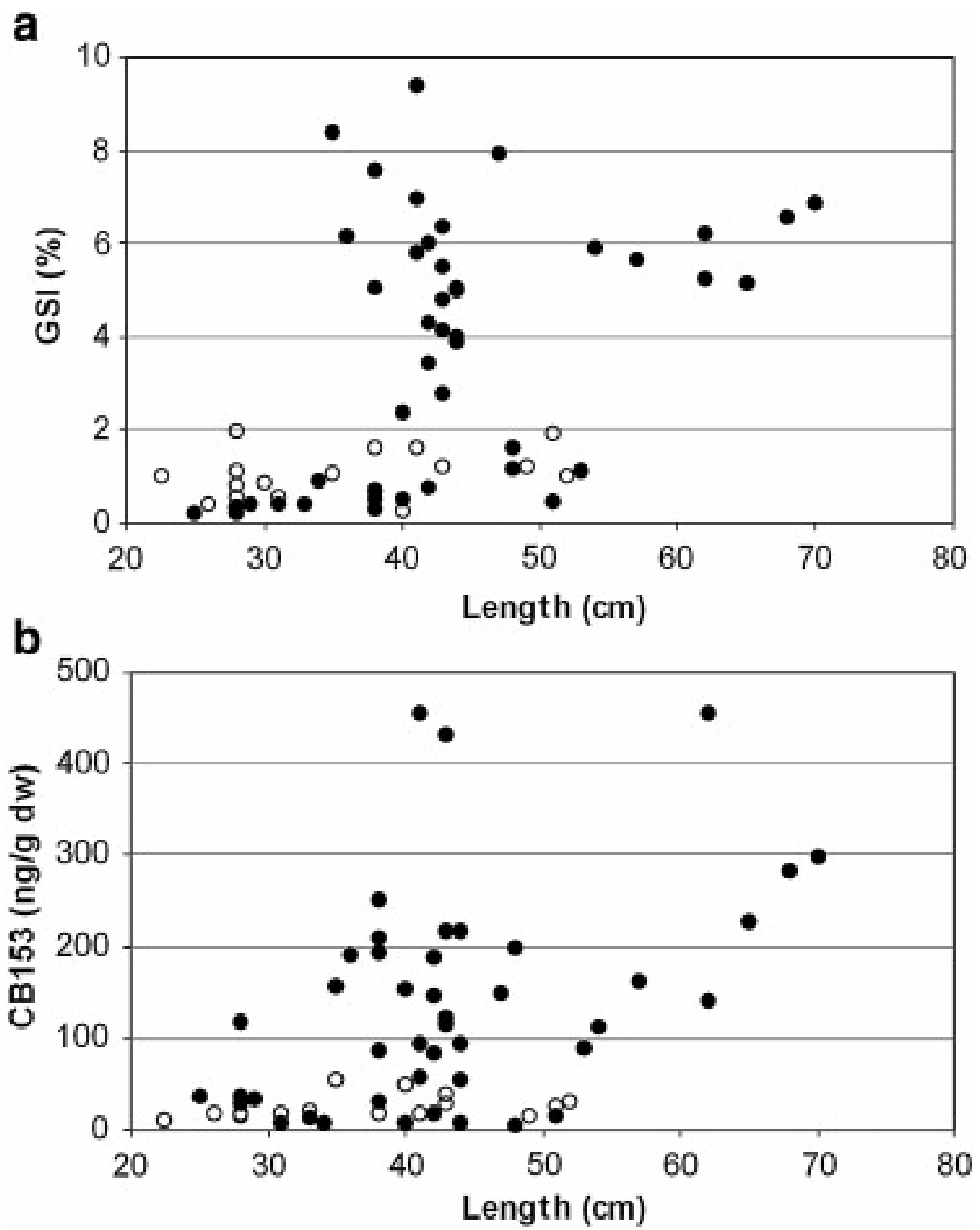

Figure 4: Relationship between body size (cm) and a) Gonadosomatic Index (GSI; \%), and b) CB153 concentrations in gonads (ng.g-1 dw) for sexed hakes. Females and males are represented with black and white circles respectively. 

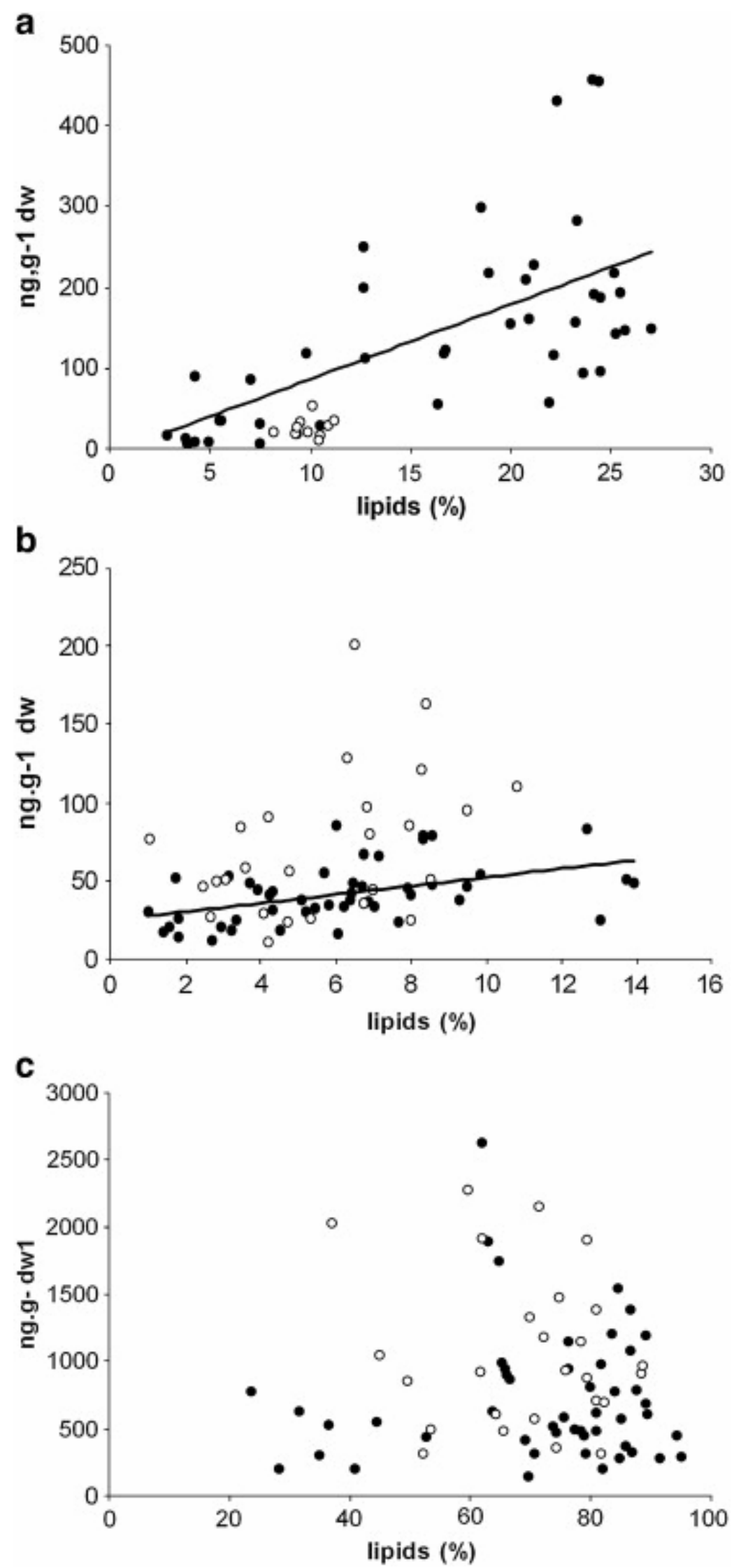
Figure 5: Concentration of CB153 versus lipid content (\%) in gonads (a), muscle (b) and liver (c) of sexed hakes. Females and males are represented with black and white circles respectively.

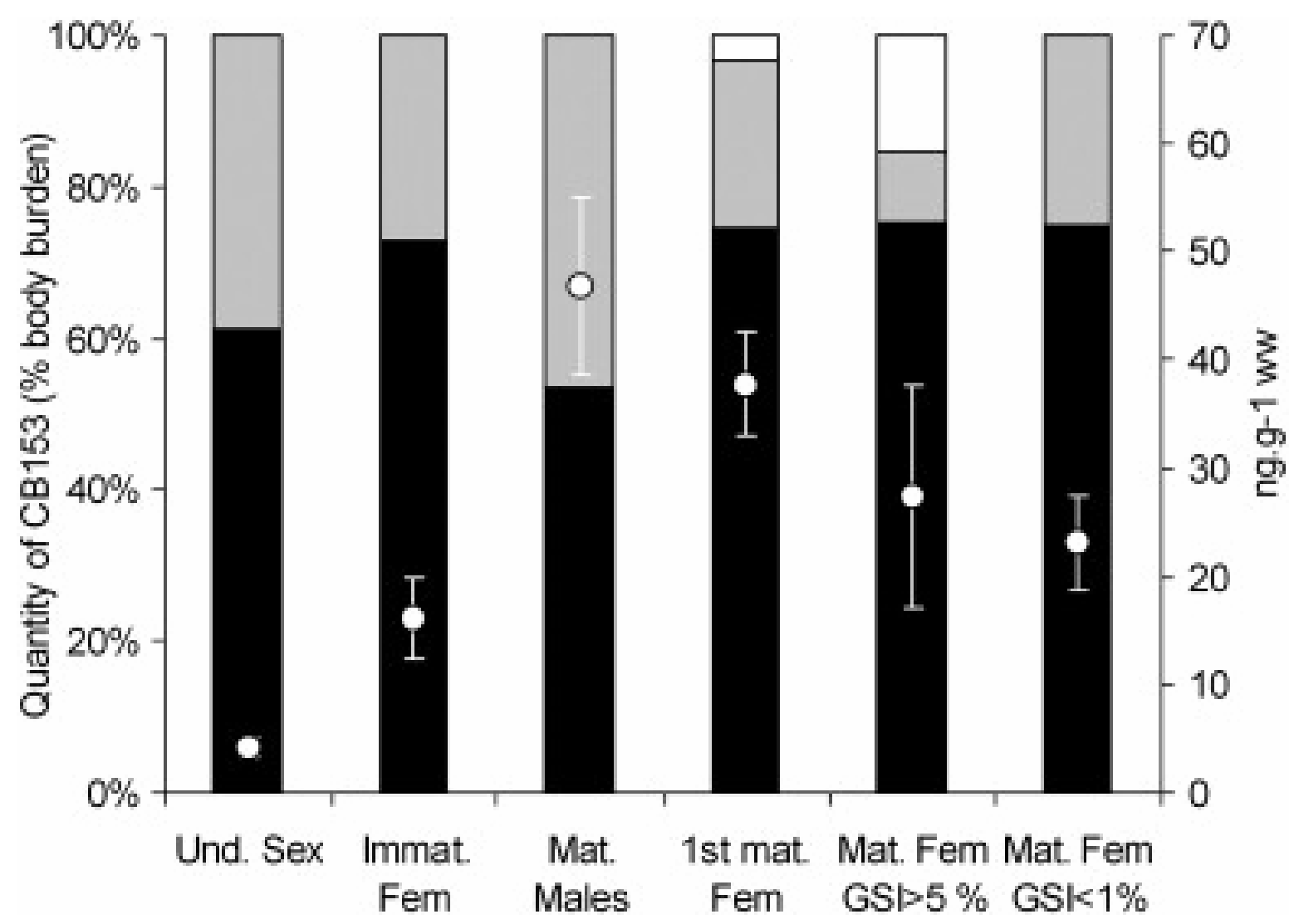

Figure 6: Organ contribution to the total CB153 body burden (\%) in the six stage (liver is represented in black, muscle in grey and gonads in white) and CB153 concentration (ng. $\mathrm{g}^{-1}$ ww) in whole fish (white circle).

\section{Tables}

Table 1: PCB and pp'DDE concentrations (ng. $\mathrm{g}^{-1} \mathrm{dw}$ ), lipid and water content (\%) in hake tissues. 


\section{Males}

Females

\begin{tabular}{|c|c|c|c|c|c|c|c|c|c|c|c|c|c|c|c|c|c|c|c|c|c|c|c|c|}
\hline & & & \\
\hline & \multirow{2}{*}{\multicolumn{3}{|c|}{$\begin{array}{c}\text { Muscle } \\
29\end{array}$}} & \multicolumn{3}{|c|}{ Liver } & \multicolumn{3}{|c|}{ Muscle } & \multicolumn{3}{|c|}{ Liver } & \multicolumn{3}{|c|}{ Gonads } & \multicolumn{3}{|c|}{ Muscle } & \multicolumn{3}{|c|}{ Liver } & \multicolumn{3}{|c|}{ Gonads } \\
\hline & & & & \multirow{3}{*}{$\begin{array}{r}\text { mean } \\
60,4\end{array}$} & \multicolumn{2}{|l|}{29} & \multicolumn{3}{|c|}{26} & \multicolumn{3}{|c|}{26} & \multicolumn{3}{|c|}{17} & \multicolumn{3}{|c|}{49} & \multicolumn{3}{|c|}{49} & \multicolumn{3}{|c|}{45} \\
\hline & \multirow{2}{*}{$\begin{array}{r}\text { mean } \\
\mathbf{7 8 , 2}\end{array}$} & & \multirow{2}{*}{$\begin{array}{l}\max \\
79,9\end{array}$} & & $\min$ & $\max$ & mean & $\min$ & $\max$ & mean & $\min$ & $\max$ & lean & $\min$ & $\max$ & mean & $\min$ & $\max$ & mean & $\min$ & $\max$ & nean & in & \\
\hline $\begin{array}{c}\text { n } \\
\text { Water (\%) }\end{array}$ & & & & & 28,1 & 75,9 & 79,1 & 77,3 & 80,4 & 44,9 & 30,3 & 78,8 & 87,0 & 83,9 & 89,6 & 78,3 & 71,2 & 81,5 & 43,5 & 26,2 & 72,4 & 78,7 & 59,9 & 88,7 \\
\hline Lipid (\%) & 3,6 & 2,1 & 4,7 & $4 \mathbf{3}, \mathbf{8}$ & 17,1 & 67,5 & 5,7 & 1,1 & 10,8 & 69,3 & 37,1 & 88,7 & 9,9 & 8,2 & 11,2 & 6,2 & 1,0 & 13,9 & 71,9 & 23,6 & 95,1 & 16,8 & 2,8 & 27,5 \\
\hline CB52 & 1,3 & 0,3 & 3,4 & 16,0 & 2,2 & 40,8 & 1,5 & 0,0 & 4,5 & 19,3 & 2,1 & 39,8 & 2,8 & 0,7 & 7,8 & 1,3 & 0,3 & 3,4 & 16,0 & 2,2 & 40,8 & 6,3 & 0,0 & 22,0 \\
\hline CB101 & 3 & 1,3 & 15,9 & 61,3 & 6,9 & 248,6 & 5,3 & 1,1 & 12,2 & 90,0 & 13,2 & 222,8 & 3,8 & 1,4 & 6,7 & 3,6 & 3 & 15,9 & 61,3 & 6,9 & 248,6 & 11, & 0,8 & 62,3 \\
\hline DDE & 17,3 & 1,3 & 65,8 & 370,1 & 10,9 & 3052,1 & 32,1 & 3,4 & 110,1 & 654,8 & 52,3 & 2249,5 & 12,5 & 2,2 & 55,6 & 17,3 & 1,3 & 65,8 & $\mathbf{3 7 0 , 1}$ & 10,9 & 3052,1 & 104,0 & 0,0 & 1148,7 \\
\hline CB110 & $\mathbf{3 , 8}$ & 0,3 & 12,6 & 65,7 & 3,6 & 222,0 & 4,2 & 0,7 & 11,0 & 79,4 & 9,9 & 215,7 & 3,3 & 1,1 & 6,2 & $\mathbf{3 , 8}$ & 0,3 & 12,6 & 65,7 & 3,6 & 222,0 & 14,7 & 0,0 & 81,8 \\
\hline CB149 & 16,4 & 2,6 & 47,8 & 237,0 & 24,0 & 674,0 & 26,1 & 4,4 & 81,4 & 372,5 & 95,7 & 851,8 & 12,4 & 5,4 & 34,5 & 16,4 & 2,6 & 47,8 & 237,0 & 24,0 & 674,0 & 45,7 & 2,8 & 161,9 \\
\hline CB11 & 5,9 & 0 & 18 & 104 & 19,8 & 3 & 9 & 2,3 & 2 & 167 & 40,4 & 414,0 & 3 & 03 & 6,5 & 0 & 8 & 18,1 & 104,0 & 19 & 380,9 & 18,7 & 0,0 & 91,2 \\
\hline CI & 1 & 11 & 0 & 725,7 & 151,0 & 2628,2 & 71,9 & 10,8 & 200 & 74,0 & 315,4 & 2276,8 & 26,0 & 9,8 & 53,8 & $\mathbf{4 1 , 7}$ & 11,6 & 85,0 & 25,7 & 151,0 & 628,2 & 27,1 & 5,8 & 456,7 \\
\hline $\mathrm{CB} 132$ & 5,1 & 0,0 & 13,7 & 78,9 & 16,8 & 187,6 & 8,0 & 0,2 & 27,7 & 121,2 & 25,9 & 296,2 & 3,2 & 0,0 & 7,3 & 5,1 & 0,0 & 13,7 & 78,9 & 16,8 & 187,6 & 15,6 & 0,8 & 56,2 \\
\hline CB105 & 4,0 & 0,5 & 17,8 & 67,6 & 6,0 & 370,4 & 7,2 & 0,7 & 24,4 & 113,7 & 29,9 & 342,3 & 3,4 & 0,0 & 11,8 & 4,0 & 0,5 & 17,8 & 67,6 & 6,0 & 370,4 & 13,7 & 0,4 & 81,7 \\
\hline CB138 & 31,1 & 6,4 & 116,4 & $\mathbf{5 2 7 , 0}$ & 105,5 & 2266,2 & 55,9 & 8,3 & 173,4 & $\mathbf{8 3 3}, 7$ & 253,9 & 1890,6 & 16,3 & 0,1 & 41,4 & 31,1 & 6,4 & 116,4 & $\mathbf{5 2 7 , 0}$ & 105,5 & 2266,2 & 92,8 & 4,0 & 394,7 \\
\hline CB 187 & 14,6 & 4,1 & 50,4 & 226,2 & 28, & 797 & 22,8 & 3,6 & 68,3 & 328,0 & 66,4 & 6 & 7 & 0,0 & 18,3 & 14,6 & 4,1 & 50,4 & 226,2 & 28,6 & 797,9 & 38,6 & 1,9 & 164,4 \\
\hline CB128 & 2 & 0,5 & 6,9 & 34 & 6 & 130,1 & $\mathbf{3 , 0}$ & 0,8 & 10,6 & $6-$ & 6,8 & 119,7 & 2,0 & 0,1 & 4 & 2,0 & 0,5 & 6,9 & $\mathbf{3 4 , 1}$ & 0,2 & 130,1 & 7,5 & 0,2 & 32,4 \\
\hline CB156 & 1,0 & 0,3 & 3,0 & 2 & 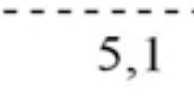 & 81,9 & $\mathbf{1 , 4}$ & 0,4 & 4,1 & 20,1 & 5,0 & 67,5 & 1,1 & 0,0 & 5,3 & 1,0 & 0,3 & 3,0 & 20,1 & 5,1 & 81,9 & 3,5 & 0,2 & 16,9 \\
\hline CB180 & 19,9 & 0,0 & 66,5 & 358,7 & 59,2 & 1337,0 & $\mathbf{3 2 , 4}$ & 5,2 & 87,8 & 522,5 & 44,8 & 1238,2 & 9,8 & 0,1 & 24,9 & 19,9 & 0,0 & 66,5 & 358,7 & 59,2 & 1337,0 & 56,4 & 2,2 & 292,3 \\
\hline CB170 & 8,7 & 0,0 & 35,2 & 158,7 & 30,0 & 589,9 & 15,4 & 2,4 & 52,4 & 252,0 & 51,0 & 6 & 4,8 & 2,2 & 9,3 & 8,7 & 0,0 & 35,2 & 158,7 & 30,0 & 589,9 & 24,5 & 0,8 & 116,2 \\
\hline CB194 & 2,6 & 0,0 & 10,4 & 47,5 & 0,0 & 172,3 & 4,0 & 0,0 & 14,2 & 77,3 & 17,5 & 200,8 & 1,2 & 0,0 & 3,0 & 2,6 & 0,0 & 10,4 & נו, & 0,0 & 172,3 & 6,9 & 0,0 & 31,1 \\
\hline
\end{tabular}

